\title{
Less of a bird's song than a hard rock ensemble
}

Article

Accepted Version

Hosfield, R., Cole, J. and McNabb, J. (2018) Less of a bird's song than a hard rock ensemble. Evolutionary Anthropology, 27 (1). pp. 9-20. ISSN 1520-6505 doi:

https://doi.org/10.1002/evan.21551 Available at https://centaur.reading.ac.uk/66741/

It is advisable to refer to the publisher's version if you intend to cite from the work. See Guidance on citing.

To link to this article DOI: http://dx.doi.org/10.1002/evan.21551

Publisher: Wiley

All outputs in CentAUR are protected by Intellectual Property Rights law, including copyright law. Copyright and IPR is retained by the creators or other copyright holders. Terms and conditions for use of this material are defined in the End User Agreement.

\section{www.reading.ac.uk/centaur}

\section{CentAUR}

Central Archive at the University of Reading

Reading's research outputs online 


\section{Less of a Bird's Song than a Hard Rock Ensemble}

Dr Robert Hosfield

Dr James Cole

Dr John McNabb

Dr Robert Hosfield, Department of Archaeology, School of Archaeology, Geography \& Environmental Science, University of Reading, Whiteknights, Reading, RG6 6AB, UK

Dr James Cole, Division of Geography, Geology and Environmental Sciences, School of Environment and Technology, University of Brighton, Cockcroft Building, Lewes Road, Brighton, BN2 4GJ, UK Dr John McNabb, Centre for the Archaeology of Human Origins (CAHO), Department of Archaeology, University of Southampton, Avenue Campus, Highfield, Southampton, SO17 1BJ, UK

Corresponding author (Hosfield): telephone: +44 (0)118 378 7632; fax: +44 (0)118 931 0279; e-mail: r.hosfield@rdg.ac.uk

Number of text pages: 26

Number of tables: 1

Number of figures: 6

Keywords: handaxe, Acheulean, culture, genetics 


\section{About the authors:}

Rob Hosfield is Associate Professor of Palaeolithic Archaeology at the Department of Archaeology, University of Reading in the UK. His main research interests are focused on the Lower Palaeolithic, with a current emphasis on hominin behaviour, survival strategies, and the taphonomy of the archaeological record.

James Cole is Senior Lecturer in Archaeology in the Division of Geography, Geology and Environmental Sciences, University of Brighton. His main research interests are focused on the Lower Palaeolithic and Early Stone Age with an emphasis on hominin cognition and the emergence of language.

John McNabb is Senior Lecturer in the Department of Archaeology at Southampton University, a former Director of their Centre for the Archaeology of Human Origins (CAHO). His interests are in the technology of the Acheulean and what this can reveal about the cognitive evolution of the hominins who made it. 


\section{Introduction}

Corbey et al. ${ }^{1}$ have written an interesting and thoughtful paper designed to provoke debate surrounding one of the most important and persistent Stone Age artefacts, the Acheulean handaxe. They challenge the long held notion that the Acheulean handaxe was a product of a cultural landscape influenced through social learning. Instead they suggest the Acheulean handaxe was, in part, under genetic control. Whilst the Corbey et al. paper was an ambitious one with many points of debate included within it, we will focus here on those areas that best match our expertise, namely the nature of Acheulean handaxes and the archaeological record.

From the perspective of this response to the Corbey et al. paper there are four areas of contention which are summarised as follows: i) They argue that Acheulean handaxes failed to track environmental variation, justified on the basis of the conservatism which they perceive in handaxes' overall form; ii) Corbey et al. consider the conservative and static nature of handaxe form to be an argument against a cultural transmission hypothesis; iii) Under a cultural transmission model, copying errors should have been introduced into the reproduction of handaxes at a rate which is not reflected in the archaeological record; iv) There are certain geographical trends, such as the separation of Acheulean handaxe traditions by the Movius Line, that are more parsimoniously explained by non-cultural factors. Off the back of these arguments, Corbey et al. suggest that the conservative Acheulean handaxe was primarily the result of genetic transmission, rather than cultural transmission models: "Raw material selection, the manufacturing process, and basic design principles would have been under genetic control, but fine-tuned through social learning".:14

Or, put another way, for Corbey et al. there should be more variability in handaxes than there is because different environments should be generating different solutions. In addition, groups of handaxe makers ought to be generating more variability than they do because social learning between generations involves the accumulation of copying errors. Finally, an extrinsically triggered 
soft genetic impetus to handaxe making is said to explain the appearance of handaxes in geographically distant locations more parsimoniously than independent invention or the maintaining of long range cultural contacts. Yet as we will demonstrate, the Acheulean handaxe record shows a mixture of short-term and local variability, alongside long-term and 'global' similarities. This 'structure' in the data set cross-cuts environments and local circumstances, and does attest to the variability expected of cultural/social learning models. At the larger scale convergences in form can be shown to be a result of both shared social learning and the limitations imposed by the mechanics of handaxe production. Moreover, animals and humans can move over considerable distances, taking their ideas with them. Distance and geographical barriers are not the insurmountable obstacles to Acheulean hominins they are often made out to be.

In short, we interpret these patterns in the archaeological record as evidence that handaxes are cultural artefacts, in-keeping with established notions of material culture: "the array of artefacts and cultural landscapes that people create according to traditional, patterned and often tacit concepts of value and utility that have been developed over time, through use and experimentation". ${ }^{2: 3}$ The remainder of our response justifies this interpretation of Acheulean handaxes with specific reference to each of the four points listed in the opening paragraph.

\section{(i) Should handaxes track environmental variation?}

Corbey et al. argue that Acheulean handaxes fail to track environmental variation, and note that this is inconsistent with models of cultural evolution. However, this argument is unconvincing because it firstly fails to acknowledge that there are examples in the archaeological record where handaxes do appear to change, in terms of their modal form, and occasionally these changes co-occur with environmental variation. Examples include the shifts in modal shape form at Swanscombe (the assemblages of the Lower Middle Gravels, Upper Middle Gravels and Upper Loams - see below for details of climate ${ }^{3}$ ) and Hoxne (the Upper and Lower Industries - different modal shapes associated 
with warm but cooling conditions $\left.{ }^{4}\right)$. Secondly, and more importantly, it fails to define what tracking of environmental change by a cultural handaxe might look like. In terms of this issue, and the related question of function, we note that use wear and polishes, cut marks, artefact/carcass associations and carcass processing evidence, ${ }^{5-12}$ as well as experimental demonstrations of their utility, ${ }^{13-16}$ have established a major role for Acheulean handaxes in butchery and carcass processing: i.e. the handaxe as butchery knife. They were probably also used for other tasks, including plant processing and the working of other materials. ${ }^{10,17,18}$ The primary role of the Acheulean handaxe as a functional, hand-held tool is also supported by their dimensions. Modern female and male subjects have expressed a preference for 'smaller' (maximum width $=65 \mathrm{~mm}$ ) and 'larger' handaxes (maximum width $=93 \mathrm{~mm}$ ) respectively in terms of ease of handling. ${ }^{19} 87.6 \%$ of the artefacts in the Marshall et al. ${ }^{20}$ sample $(n=3556)$ have a maximum width value between 50 and $110 \mathrm{~mm}$, suggestive of sizes in an experimentally-demonstrated preferred range for a hand-held tool, while acknowledging the limited evidence for Acheulean hominin hands. ${ }^{21,22}$

This is important because we question why a hand-held butchery knife or multi-purpose tool should necessarily be expected to track environmental variation, given that their functions are integral to hunter-gatherer lifestyles. One might just as well ask why modern knives, despite their extensive cultural variations in shape and appearance, are all characterised by the same fundamental morphology: a handle to grasp and a blade with one or two edges with which to cut. As MacDonald ${ }^{23}$ has highlighted with reference to hunting, it is skills, knowledge and experiences which are likely to track environmental variation - e.g. changes in stalking strategies when hunting horse herds in open grasslands as opposed to red deer in woodland, or just changes across the seasons. Thus behaviour changes, not material culture, in this case.

\section{(ii) How variable are Acheulean Handaxes?}


We argue that there is multi-scalar variability in the handaxe record, and feel that this variability has been fundamentally simplified and misrepresented by Corbey et al.'s macro-scale perspective. They maintain that handaxes are conservative in form and, drawing on the results of Kempe et al. ${ }^{24}$ argue that they do not meet the range of variability that would be expected from an artefact that is influenced through cultural interplays: "Given that copying error would inevitably have occurred if individuals had acquired the behaviors required to produce handaxes via social learning, this supports the idea that handaxes were not fully cultural artifacts and may have been under at least partial genetic control." ${ }^{1: 9}$ In Corbey et al.'s defence, their perspective of the Acheulean handaxe is one often held, to a greater or lesser extent, by a number of researchers. ${ }^{\text {e.g. }} .25,26$ It stems from a popular belief, once expressed by Glynn Isaac - the 'variable sameness' of the Acheulean. ${ }^{27}$ However, off the back of more recent work ${ }^{28-34}$ we believe that the conservative perception of the Acheulean is a gross simplification of a complex archaeological record.

\section{(iia) Is the Acheulean handaxe record being misrepresented?}

When seeking to characterise the Acheulean handaxe record one must discuss artefact variations with reference to both time and place and the changing scales and resolution of the record. We will explore this through both assemblage and site-specific examples and macro-scale data sets.

To start with a site-specific example, at Swanscombe in the Thames Valley (UK) there is a clear shift from small and pointed handaxe-dominated assemblages in the Lower Middle Gravels (temperate conditions of Hoxnian IIla) to the larger pointed and ovate mixed assemblages of the Upper Middle Gravels (Hoxnian IIla-IIIb, with a cooling climate suggested at the top of the Upper Middle Gravels); and then from both of these layers in MIS [marine isotope stage] 11c, to ovate-dominated assemblages in the temperate Upper Loam (MIS 11a). ${ }^{35-40}$ It is possible that these variations reflect the changing characteristics of the available raw materials, ${ }^{38}$ although local extirpation events followed by renewed pulses of hominin dispersal may also be factors. ${ }^{32}$ Away from the intra-site 
scale, we can see evidence for handaxe variations which in some cases do not map consistently onto environmental factors. At the landscape scale in south-east England there is evidence for similar handaxe shapes associated with different habitat settings (e.g. ovate-dominated assemblages and the Boxgrove waterhole/coastal plain, the Elveden fluvial landscape and the chalk uplands of Caddington). ${ }^{38}$ Equally, there are examples of different handaxe shapes associated with the same settings (e.g. ovate- and point-dominated assemblages occurring respectively at the fluvial sites of Wansunt Pit/Bowman's Lodge and Furze Platt). ${ }^{38}$ The handaxe-making practices of individual hominin groups may explain some of these landscape-scale patterns, although the difficulties in identifying contemporary assemblages within a single marine isotope stage, even across the same landscape, are a major challenge to such interpretations.

At the multiple-MIS scale, White ${ }^{32}$ (see also ${ }^{33,41,42}$ ) has recently demonstrated clear shifts in the modal shape tendencies of British handaxe assemblages from MIS 13 (c. 533-478kya [all MIS dates after ${ }^{43}$ ]; Roe Groups V [crude, narrow ovates] and VII [well-made, 'rounded' ovates]) and MIS 11 (c. 424-374kya; Groups II [squat, broad-pointed handaxes, with a strong ovate element] and VI [pointed ovates, with a twisted ovate component]; see also ${ }^{44}$ ) to MIS 9 (c. 337-300kya; Groups I [pointed handaxes, with cleavers] and III [pointed, plano-convex, forms]). White has raised the possibility that these changes reflect the cultural repertoires of different groups, grounded in the cultural resonance of handaxe shapes for Acheulean hominins. At the largest scale, the contrast between the European focus on handaxe production from nodules (façonnage) and the African emphasis on large flake blanks (débitage) has often been thought to relate at least in part to the relative workability of the raw materials in the two regions (e.g. the 'Roe line' ${ }^{45}$ ), but Sharon ${ }^{46}$ has also emphasised the impact of functional or cultural preferences upon knapping strategies. At a macro-scale view this could potentially be seen as a genetically-structured variation, not least because of the major geographical barriers such as the Saharan and Arabian Deserts which might disrupt or block cultural transmission. But we note that these 'barriers' were not permanent, for example with periods of 'Green 
Saharan'47,48 and 'Green Arabian' ${ }^{49,50}$ conditions, and that hominins, and presumably their artefacts and ideas, sometimes moved across these barriers. Moreover, at the site and regional scales within both Europe and Africa, for example the production of flake cleavers in Middle Pleistocene Spain, ${ }^{51}$ we see a handaxe record that is locally varied, with variations that extend beyond raw materials, and don't map onto simple latitudinal and/or longitudinal environmental variations. There is thus clear evidence for variability, from the site to the landscape to the continent, and variability which extends beyond raw material factors and which we see as too varied to meet the 'slight local variance' and 'social fine-tuning' reading of the artefact record that is favoured by Corbey et al.

\section{(iib) What were the contexts and requirements of handaxe production?}

The site and artefact record allows us to make two key statements regarding the contexts and requirements of handaxe production:

- $\quad$ There are two main hominin species responsible for the Acheulean; Homo erectus sensu lato and Homo heidelbergensis. Imagine you are a young hominin growing up in a small, possibly genetically related band of such hominins. Amongst your first conscious memories will be the sights, sounds and smells of individuals making handaxes, using them, discarding them, and then making new ones. We emphasise that examples such as the GTP-17 horse butchery site at Boxgrove are indicative of individual handaxe making, ${ }^{52}$ while the evidence for fire-side handaxe working at sites such as Beeches Pit ${ }^{53,54}$ and, cautiously, Foxhall Road ${ }^{55}$ is suggestive that young hominins were exposed to these technological processes and the associated social contexts in which the artefacts were made. You would therefore grow up familiar with the processes and products of handaxe production as expressed by your elders and peers at that particular time and place - a form of social learning known as imitation learning. ${ }^{56}$ This is also supported by the non-intuitive nature of certain aspects of handaxe production, such as platform preparation. ${ }^{57}$

- $\quad$ Although some handaxes may never have been intended for use, such as the so-called giants in excess of $270 \mathrm{~mm}$ length, ${ }^{58}$ it is clear that most had a utilitarian function and a size appropriate to 
hand-held tasks (Section i). This means an emphasis on a cutting edge, whose length and character are appropriate for the job in mind. Leaving aside the thorny question of whether different kinds of handaxes had different functions, the biface becomes in effect a device for delivering an edge to a job. Outline shape and overall morphology are a function of, and a reflection of, the extent and location of the cutting edge.

So, in terms of their archaeological context, handaxes are a product of knowledgeable social learning and are made to be used. Conceptually, procedurally and functionally they are made in societies by societies. The social dimension is therefore impossible to discount.

\section{(iic) Is there not enough handaxe variability for the cultural interpretation?}

Corbey et al. refer to a commonly held belief that there is not much variability in the Acheulean - a million and a half years of effective stasis in tool manufacture where more or less the same things get made all the time, everywhere: Isaac's 'variable sameness'. In effect, this refers to handaxe shape and morphology. The reason this is important to Corbey et al.'s argument is that mechanisms of social learning, like imitation, have a low fidelity - they naturally produce copying errors, meaning that there should be endless variation in handaxe morphology over $1.5 \mathrm{my}$, if their shape was determined by social factors. Corbey et al. argue that we just don't see that. Instead, they suggest it is more parsimonious to argue that handaxe shape is governed by a conservative mechanism that inhibits variability - genetics.

We have already argued (Section iia) that there is in fact a great deal of variability in the handaxe record, operating at different scales. What we wish to further emphasise here is that this variability occurs within limits naturally imposed by concept, utility, raw material (sometimes), and process of manufacture. This is something Corbey et al. have failed to appreciate. 
We will start our argument with Boxgrove..$^{52,59}$ The Unit 4c land surface was open for somewhere between seventy five and one hundred years, ${ }^{52}$ the handaxes on the surface perhaps the product of no more than four or five generations of hominins (Fig. 1). There is a basic bauplan ${ }^{28}$ or conceptual template ${ }^{60}$ present - a cutting edge around all (or most) of the handaxe's circumference; often accompanied by a tranchet; made by bifacial soft hammer thinning and shaping; ${ }^{61}$ tending to narrow toward the tip. At first glance the variable sameness seems apparent.

This is where the constraints come in. Since the Boxgrove modality/conceptual template involves a cutting edge around all or most of the circumference, made by extensive bifacial soft hammer thinning, the handaxe will usually end up with convex edges and a lenticular cross section in two dimensions (length and width). In effect, the handaxe will be an ovate (widest in the middle third) or a cordate (widest in the basal third). Here, what you make, why you make it, and how you make it initially reduces the range of potential morphological variability.

The issues of scale come into play here too. There are few sites where the degree of temporal resolution approaches Boxgrove: similarity in outline form because of a shared template across several generations is readily conceivable at this site - strong social learning. ${ }^{62,63}$ We think that a strong argument in favour of the social template at Boxgrove is the unusually high presence of tranchet sharpening (Fig. 1). As far as we know butchery/dismemberment practices at Boxgrove were not so different from elsewhere ${ }^{8}$ so the unusually high frequency of tranchet blows is likely to be a socially-learned practice. There is surely no gene for tranchet blows and we argue that the spatial and temporal restriction of these and other idiosyncrasies have to be evidence of strong social learning and not the social 'fine-tuning' described by Corbey et al. ${ }^{1: 14}$

In terms of Corbey et al.'s parsimony argument, which is the most likely explanation for Boxgrove's conservatism in outline shape? An as yet unidentified predisposition to 'sameness', or a basic social 
modality instilled from growing up with handaxe makers who were socially conservative in what they made? We see the Boxgrove patterns in much the same manner as Gowlett ${ }^{64}$ has interpreted Beeches Pit and Kilombe: “...each time an individual makes a specimen [an Acheulean handaxe], they are in effect moving a 'personal pointer' to a particular point within the zone of all allowable permutations made by the group"..."each Beeches Pit specimen so distinctively made is made by an individual working within a group norm and collective cultural memory" $.64: 52 \& 64$

Moving on to the 'variability' aspect, despite the constraints on shape there actually is a lot of variability present when individual outline shapes are compared (Fig. 1-2). In fact, within the limits imposed, it is actually difficult to imagine many other variations on shape. Although broadly contemporary with Boxgrove (late MIS 13), Warren Hill ${ }^{36,65,66}$ is a palimpsest of unknown duration, its handaxes swept off a floodplain and along channels by high energy streams. Up to two interglacials may be represented (MIS 13 for the unrolled series, MIS 15 [c. 621-563kya] for the rolled series), ${ }^{34,42}$ but a similar mental construct is present - with emphasis on a cutting edge all the way around, and probable use of a soft hammer for extensive thinning and shaping (Fig. 2). Once again it is clear that, within the raw material boundaries set, almost every conceivable shape is explored - and it is unsurprising that the range of shapes is greater than at Boxgrove, since several (shared?) social traditions/conceptual templates may be included in this palimpsest. However, we should not assume that just because a social tradition at one site imposes a tighter constraint on form, that this is the same elsewhere. Some hominin groups may have explored greater diversity than others.

Cuxton $^{67-69}$ is a classically pointed assemblage for which an MIS 7 date (c. 243-191kya) is accepted here, ${ }^{41,69}$ although MIS 9 is also suggested on typological grounds. ${ }^{33}$ Here the modal concept is different to Boxgrove/Warren Hill (Fig. 3). It revolves around making a cutting edge on the tip and upper two-thirds of the handaxe (many of which will be raw material constrained, but not 
necessarily all). Yet, while the modal concept is different, a clear bauplan is evidently present, but within it we still see a marked degree of variability.

Handaxes can therefore be seen as a continuum of morphological variability. ${ }^{60}$ At one end of the continuum are tools with a short length of bifacial cutting edge, possibly expediently made when a bifacial edge was required for a moment's work. These non-classic forms express the concept of a handaxe, but do not have the extensive thinning and shaping normally associated with them. At the opposite end of the spectrum are the classic handaxes which conform to our intuitive understanding of what these tools should look like - the extensively thinned and shaped tools from Boxgrove, Warren Hill, Cuxton, and elsewhere. They can be long, short, wide or narrow and every variation inbetween (Fig. 4). If we think about their edges, they can be straight, or concave, or convex in the middle (ovate), or convex toward the base (cordate), they can have a smooth regular outline shape, or an irregular one; the two edges don't even have to look the same. They can retain cortex on one or both faces, or not, and look bilaterally symmetrical, or not. They can be roughly thinned and shaped, show extra working at the tip or on some other part of the margin, or they can show careful and extensive thinning and shaping all over their surfaces. Twenty minutes looking through the images on the ADS (Archaeology Data Service) Marshall et al. data-set ${ }^{20}$ should make this point forcibly. The spread of potential handaxe morphological space in the ADS sample is represented by the $X$ and $Y$ axes of Fig. 4, but the concentration of the data cloud into a narrower space is a result of the social and technical constraints discussed above. Within this 'realistic' morphological space, and within which handaxe shape could vary, we see that a huge (and continuous) variation in shape is actually present - a far cry from the limited variability envisaged by Corbey and colleagues.

Corbey et al. have taken a very simplistic view of handaxes, almost caricaturing them. The variability that is really present in the Acheulean resides in the spaces between those socio-conceptual, procedural and functional constraints that the need for a stone knife imposes. 
So it is evident that there are constraints on handaxe manufacture, both social and material. It is also evident that there is variability in the Acheulean handaxe record. But how much is there, how is that variability patterned in quantitative terms, and what are the implications for cultural versus genetic interpretations? Our analysis of the largest currently available data-se ${ }^{20}$ has indicated the following patterns:

- Assemblages from a wide span of Acheulean space and time are not significantly different to one another in terms of their type and degree of overall variability (Fig. 5).

- Individual assemblages with a high degree of temporal control (e.g. a palaeosol representing decadal timescales, such as at Boxgrove ${ }^{52}$ ) are characterized by less variability than timeaveraged assemblages (e.g. Warren Hill65; Fig. 6).

This is the actual character of the Acheulean handaxe record, and we interpret it as follows:

(i) The lack of significant difference between assemblages across the entire Marshall et al. data-set reflects the mechanical constraints of handaxe production, which results in a shared core of variability (e.g. a cutting edge all the way around the perimeter and extensive soft hammer thinning resulting in a convex base and sides). Thus shape is not infinitely variable - it tends to cluster. This is evident in both bivariate plots of shape (Fig. 4; e.g. note that handaxes where the tip and base are wider than the middle are very unusual) and in multivariate analyses of shape (Fig. 5; note the concentration of artefacts in the central core of the plot).

(ii) However we do not interpret this clustering as evidence of genetically controlled handaxe production, because individual assemblages also deviate, to greater and lesser extents, from the core area (Fig. 5; e.g. note the occurrence of handaxes from several sites in the bottom-right of the plot - i.e. handaxes where the widest point is located higher up the axe). 
(iii) Such deviations could of course, and sometimes do (e.g. at Cuxton ${ }^{70}$ ), reflect local raw material circumstances. However, we do not interpret these deviations as purely raw material-driven, because where the archaeological record enables high-resolution temporal control (e.g. the 75-100 year palaeosol at Boxgrove ${ }^{52}$ ) there is also evidence for reduced variability (e.g. note the clustering of the Boxgrove handaxes in the central core of Fig. 6). Since population continuity can reasonably be predicted on such sites, we interpret this reduced variability as evidence for handaxe production shaped through individual cultural drivers (i.e. inherited ways of doing), within the existing mechanical and raw material constraints. Such reduced variability is also evident on other highresolution sites - for example the grey clay surface at Foxhall Road..$^{55}$

(iv) By contrast, where the archaeological record does not permit high-resolution temporal control (e.g. the time-averaged fluvial-context assemblage at Warren Hill ${ }^{71}$ ) there is evidence for higher levels of variability (e.g. note the wider dispersal of Warren Hill handaxes in the right-hand extremes of Fig. 6 - i.e. handaxes where tip and base widths tend to be similar). Since there is no evidence for major raw material change at many of these individual sites (e.g. flint at Warren Hill, quartzite at Montagu Cave, andesite at Pniel $6^{20}$ ), this is most parsimoniously explained by accumulated copying errors or population discontinuity.

(iii) Are copying error models appropriate for providing a base-line against which to compare

\section{handaxes?}

We also question Corbey et al.'s reliance on Kempe et al. ${ }^{24}$ as a means of demonstrating that Acheulean handaxes are characterised by less variability than that expected from copying error models. In our opinion Kempe et al. used an inappropriate task, re-sizing a 2D handaxe image on an iPad to match an existing image, to test the accumulated copying error model, the results of which were then compared to handaxe size data from the Marshall et al. data-set. ${ }^{20}$ The use of this methodology as an analogy to the manufacture of handaxes is flawed for a number of reasons. Firstly, perceptual re-sizing of a 2D image on a digital screen is primarily reliant on hand-eye 
coordination (and perhaps also the degree of an individual's care and attention to the task), whereas the knapping of a 3D object in stone requires hand-eye coordination, technique, understanding of fracture mechanics and forward planning (e.g. with specific reference to platform preparation and handaxe thinning $\left.{ }^{57}\right)$ : in short the two tasks are simply not comparable. Secondly, as any modern knapper will know, the process is organic and fluid, in which knapping decisions and strategies are frequently modified in response to the last blow and its impact on the stone - in short, it sometimes feels as though the nodule or blank is 'fighting back'! An iPad does not. Finally, their experiment used modern human subjects, with modern human hand-eye coordination. While we are not stating with certainty that modern human abilities would result in lower levels of variability compared to those of the Acheulean handaxe makers, we think it is likely that their respective abilities were different.

These points suggest that there should be more variability in the handaxe record than the predictions of Kempe et al., ${ }^{24}$ which might at first glance seem to be supporting Corbey et al. However this is not the case for two reasons. Firstly, as we demonstrated in section ii above, Corbey et al. have significantly under-estimated the degree of variation in the Acheulean record. Secondly, and most seriously, given the wide span of Acheulean space and time represented in the Marshall et al. data-set (1 myr+), the overall variability, or lack of it, in this data cannot be used (contra Corbey et al.) to securely reject a copying error model. This is because there is no way of demonstrating population continuity, particularly in regions such as Eurasia which were likely subject to source and sink population dynamics. ${ }^{72}$

\section{(iv) Handaxe geography}

Corbey et al. draw attention to the perceived geographic problem of Acheulean handaxes being present c. $1500 \mathrm{~km}$ beyond the Movius Line. ${ }^{73,74}$ They suggest the presence of handaxes in the Bose Basin and at other sites, e.g. ${ }^{75,76}$, is due to their genetic transmission hypothesis. In short, a genetic 
ability to produce a handaxe lay dormant within Chinese hominin populations until proper raw materials became available, at which point those abilities were subsequently expressed. Their reading of the East Asian handaxe record is partly grounded in the notion that high quality lithic raw materials are rare to the east of the Movius Line, but were periodically exposed through forest fires in river basins. ${ }^{1,73}$ For Corbey et al. the key challenge in the East Asian record to cultural models is how were the behaviours involved in handaxe manufacture maintained and/or acquired by hominins c. $1500 \mathrm{~km}$ from the Movius Line?

Their reasons for a genetic explanation stem from a belief that it would be unlikely that Chinese hominins would have maintained contact with handaxe-using groups to the west of the Movius Line, and that it is even more unlikely that the cultural knowledge of handaxe manufacture would have been transmitted across generations without some of those generations ever having produced them. They also suggest that a convergent evolutionary explanation for Chinese handaxe manufacture is a less parsimonious explanation than their gene expression-based explanation.

However Dennell77 has now convincingly rejected the Movius Line concept, and while there is no need for us to repeat all his arguments here, Dennell's emphasis on the interglacial connections between West Asia and East Asia and the presence of both bifacial and non-bifacial assemblages in China and Korea highlights that the region should not be used as a special case as Corbey et al. have done. Instead, we will focus in this section on discussing the variation of the Acheulean in terms of broader geographical patterns.

As has been well-documented, ${ }^{42,78}$ Acheulean handaxe-making is rarely continuous in the Lower Palaeolithic archaeological record, both geographically and chronologically. There are areas such as central Europe where handaxes are very rare or completely absent (although this perspective may also be influenced by overly-narrow definitions of the Acheulean ${ }^{42,77}$ ), while in regions which are 
widely defined as 'Acheulean' (e.g. western Europe) there are both individual sites and short periods of time where handaxes were not made. ${ }^{79}$ Can these patterns be explained with reference to Corbey et al.'s genetic explanation as applied to East Asia - i.e. that the handaxe gene was awaiting suitable raw materials? We argue not, because one of us $(\mathrm{JM})^{42}$ has previously noted that while raw material constraints sometimes did influence technological choices at these European sites (e.g. at Bilzingsleben and Vérteszöllös), critically this was not always apparent (e.g. at Arago). Instead other factors, such as site type, length of occupation, range of activities, patterns of social learning, and distinct hominin populations and their mobility, ${ }^{80}$ are more likely to explain at least some of these patterns.

This last issue of mobility is central to Corbey et al.'s emphasis on the distance from the edge of the Movius Line to the nearest example of handaxes being produced in the Bose Basin, c. $1500 \mathrm{~km}$, as problematic. They saw this distance as too great for cultural contact to be maintained between those hominins to the east and west of the Movius Line, and argue that it would have taken hominins several generations to travel that distance. Our concern here is not with the Movius Line pattern per se, given the increasing doubts over the concept and the interpretations of the underlying East Asian data. ${ }^{77}$ But we do argue that the occurrence of occasional handaxes in any 'handaxe-free' regions (e.g. central Europe), or alternations between handaxe and non-handaxe assemblages on individual sites or within individual regions, do not require a genetic explanation. Instead we favour hominin mobility and population dynamics. While much remains to be understood about these issues, hunter-gatherer mobility data ${ }^{81}$ from a range of ecological zones offers a useful insight into the spatial and temporal scales of hunter-gatherer movement (Table 1). The data vary quite substantially depending on the hunter-gatherer groups' degree and patterns of mobility (e.g. seasonal circular movements or biannual migrations) and subsistence strategy, and we do of course acknowledge that modern hunter-gatherer groups are not a direct analogy for Acheulean hominins. However, and in combination with increasing isotopic insights into animal 
migration data, ${ }^{82,83}$ these data highlight the potential for hunter-gatherers, and their material knowledge and practices, to move substantial distances over years rather than decades or centuries. Such larger-scale shifts in population might occur in response to changes in climate and environment, as recently argued for the Clactonian/Acheulean patterns in Britain during MIS $11 .^{80}$

\section{Conclusion - why we think handaxes are cultural}

In summary, we critique Corbey et al.'s reading of the handaxe record, in particular its degree of variability, evident across a wide range of spatial and temporal scales. We question their reliance on out-dated geographical patterns (the Movius Line), and argue that environmental tracking should not necessarily be expected in a butchery knife and that its absence does not make knife manufacturing a genetic predisposition. As for why we see handaxes differently, we emphasise the social contexts of their production and the evidence for site-specific modal forms and for locallyexpressed, short-lived, idiosyncratic traits in the Acheulean record: the Boxgrove tranchet blows, ${ }^{52}$ the S-twist proportions in British MIS 11 assemblages, ${ }^{44}$ the ficrons and cleavers at Cuxton, ${ }^{41}$ or the planform asymmetry at Broom. ${ }^{71}$ We maintain there is much more structured variability in these socially-learned, socially-made, cultural artefacts than Corbey et al. acknowledge.

\section{References}

[1] Corbey R, Jagich A, Vaesen K, Collard M. 2016. The Acheulean Handaxe: More Like a Bird's Song Than a Beatles' Tune. Evolutionary Anthropology 25:6-19.

[2] Schlereth TJ. 1985. Material culture: A research guide. Lawrence, KS: University Press of Kansas. [3] Conway B, McNabb J, Ashton NM. 1996. Excavations at Barnfield Pit, Swanscombe 1968-1972. London: British Museum.

[4] Singer R, Gladfelter BG, Wymer JJ. 1993. The Lower Palaeolithic site at Hoxne, England. Chicago: Chicago University Press. 
[5] Keeley LH. 1980. Experimental Determination of Stone Tool Uses. Chicago: University of Chicago Press.

[6] Keeley LH. 1993. Microwear analysis of lithics. In: Singer R, Gladfelter BG, Wymer J, editors. The Lower Paleolithic site at Hoxne, England. Chicago: University of Chicago Press. p 129-138.

[7] Mitchell JC. 1995. Studying Biface Butchery at Boxgrove: Roe Deer Butchery with Replica Handaxes. Lithics: The Newsletter of the Lithic Studies Society 16:64-69.

[8] Parfitt SA, Roberts MB. 1999. Human modification of faunal remains. In: Roberts MB, Parfitt SA, editors. Boxgrove: A Middle Pleistocene Hominid Site at Eartham Quarry, Boxgrove, West Sussex. London: English Heritage. p 398-419.

[9] Lhomme V. 2007. Tools, space and behaviour in the Lower Palaeolithic: discoveries at Soucy in the Paris basin. Antiquity 81:536-554.

[10] Solodenko N, Zupancich A, Cesaro SN, Marder O, Lemorini C, Barkai R. 2015. Fat residue and use-wear found on Acheulian biface and scraper associated with butchered elephant remains at the site of Revadim, Israel. PLoS ONE 10(3):e0118572.

[11] Bello SM, Parfitt SA, Stringer CB. 2009. Quantitative micromorphological analyses of cut marks produced by ancient and modern handaxes. Journal of Archaeological Science 36:1869-1880.

[12] Yravedra J, Domínguez-Rodrigo M, Santonja M, Pérez-González A, Panera J, Rubio-Jara S, Baquedano E. 2010. Cut marks on the Middle Pleistocene elephant carcass of Áridos 2 (Madrid, Spain). Journal of Archaeological Science 37(10):2469-2476.

[13] Jones PR. 1980. Experimental butchery with modern stone tools and its relevance for Palaeolithic archaeology. World Archaeology 12(2):153-165.

[14] Jones PR. 1981. Experimental Implement Manufacture and Use; A Case Study from Olduvai Gorge, Tanzania. Philosophical Transactions of the Royal Society of London. Series B, Biological Sciences 292:189-195. 
[15] Jones PR. 1994. Results of experimental work in relation to the stone industries of Olduvai Gorge. In: Leakey M, Roe D, editors. Olduvai Gorge: Excavations in Beds III and IV, and the Masek Beds, 1968-1971. Cambridge: Cambridge University Press. p 254-298.

[16] Machin A, Hosfield R, Mithen SJ. 2007. Why Are Some Handaxes Symmetrical? Testing the Influence of Handaxe Morphology on Butchery Effectiveness. Journal of Archaeological Science 34:883-893.

[17] Binneman JNF, Beaumont P. 1992. Use-Wear Analysis of Two Acheulean Handaxes from Wonderwerk Cave, Northern Cape. South African Field Archaeology 1:92-97.

[18] Dominguez-Rodrigo M, Serrallonga J, Juan-Tresserras J, Alcala L, Luque L. 2001. Woodworking activities by early humans: a plant residue analysis on Acheulean stone tools from Peninj (Tanzania). Journal of Human Evolution 40:289-299.

[19] Walker J, Lee K. 2016. Relationship between Acheulean biface dimensions and hand size. Lithics: Journal of the Lithic Studies Society 37:5-14.

[20] Marshall G, Dupplaw D, Roe D, Gamble C. 2002. Lower Palaeolithic technology, raw material and population ecology. York: Archaeology Data Service (doi:10.5284/1000354).

[21] Tocheri MW, Orr CM, Jacofsky MC, Marzke MW. 2008. The evolutionary history of the hominin hand since the last common ancestor of Pan and Homo. Journal of Anatomy 212(4):544-562.

[22] Arsuaga JL, Carretero J-M, Lorenzo C, Gómez-Olivencia A, Pablos A, Rodríguez L, GarcíaGonzález R, Bonmatí A, Quam RM, Pantoja-Pérez A and others. 2015. Postcranial morphology of the Middle Pleistocene humans from Sima de los Huesos, Spain. Proceedings of the National Academy of Sciences 112(37):11524-11529.

[23] MacDonald K. 2007. Ecological hypotheses for human brain evolution: evidence for skill and learning processes in the ethnographic literature on hunting. In: Roebroeks W, editor. Guts and Brains: an integrative approach to the hominin record. Leiden: Leiden University Press. p 107-132. [24] Kempe M, Lycett S, Mesoudi A. 2012. An experimental test of the accumulated copying error model of cultural mutation for Acheulean handaxe size. PLoS ONE 7(11):e48333. 
[25] Klein RG. 2000. Archeology and the evolution of human behavior. Evolutionary Anthropology $9(1): 17-36$

[26] Hodgson D. 2009. Evolution of the visual cortex and the emergence of symmetry in the Acheulean techno-complex. Comptes Rendus Palevol 8(1):93-97.

[27] Isaac GL. 1977. Olorgesailie: archeological studies of a Middle Pleistocene lake basin in Kenya. Chicago: Chicago University Press.

[28] Lycett SJ, Gowlett JA. 2008. On questions surrounding the Acheulean 'tradition'. World Archaeology 40(3):295-315.

[29] Cole J. 2015. Examining the Presence of Symmetry within Acheulean Handaxes: A Case Study in the British Palaeolithic. Cambridge Archaeological Journal 25:713-732.

[30] Cole J. 2015. Handaxe Symmetry in the Lower and Middle Palaeolithic: Implications for the Acheulean Gaze In: Coward F, Hosfield R, Pope M, Wenban-Smith F, editors. Settlement, Society and Cognition in Human Evolution: Landscapes in Mind. Cambridge: Cambridge University Press. p 234257.

[31] McNabb J, Cole J. 2015. The Mirror Cracked: Symmetry and Refinement in the Acheulean Handaxe. Journal of Archaeological Science Reports 3:100-111.

[32] White MJ. 2015. 'Dancing to the rhythms of the biotidal zone': Settlement history and culture history in Middle Pleistocene Britain. In: Coward F, Hosfield R, Pope M, Wenban-Smith F, editors. Settlement, Society and Cognition in Human Evolution: Landscapes in Mind. Cambridge: Cambridge University Press. p 154-173.

[33] Bridgland DR, White MJ. 2015. Chronological variations in handaxes: patterns detected from fluvial archives in north-west Europe. Journal of Quaternary Science 30(7):623-638.

[34] Moncel M-H, Ashton N, Lamotte A, Tuffreau A, Cliquet D, Despriée J. 2015. The early Acheulian of north-western Europe. Journal of Anthropological Archaeology 40:302-331.

[35] Wymer JJ. 1968. Lower Palaeolithic Archaeology in Britain, as Represented by the Thames Valley. London: John Baker. 
[36] Roe DA. 1968. British Lower and Middle Palaeolithic handaxe groups. Proceedings of the Prehistoric Society 34:1-82.

[37] Hubbard R. 1996. The palynological studies from the Waechter excavations. In: Conway B, McNabb J, Ashton N, editors. Excavations at Barnfield Pit, Swanscombe, 1968-72. London: British Museum (Occasional Paper 94). p 191-200.

[38] White MJ. 1998. On the Significance of Acheulean Biface Variability in Southern Britain. Proceedings of the Prehistoric Society 64:15-44.

[39] Ashton N, Lewis SG, Parfitt SA, Penkman KE, Coope GR. 2008. New evidence for complex climate change in MIS 11 from Hoxne, Suffolk, UK. Quaternary Science Reviews 27(7):652-668.

[40] Ashton NM. 2016. The human occupation of Britain during the Hoxnian Interglacial. Quaternary International 409(B):41-53.

[41] Wenban-Smith FF. 2004. Handaxe typology and Lower Palaeolithic cultural development: ficrons, cleavers and two giant handaxes from Cuxton. Lithics: Journal of the Lithic Studies Society 25:11-21.

[42] McNabb J. 2007. The British Lower Palaeolithic: Stones in Contention. Abingdon: Routledge. [43] Lisiecki LE, Raymo ME. 2005. A Pliocene-Pleistocene stack of 57 globally distributed benthic $\delta 180$ records. Paleoceanography 20(1).

[44] White MJ. 1998. Twisted ovate bifaces in the British Lower Palaeolithic: some observations and implications. In: Ashton N, Healy F, Pettitt P, editors. Stone Age Archaeology: Essays in Honour of John Wymer. Oxford: Oxbow Books. p 98-104.

[45] Gamble C, Marshall G. 2001. The shape of handaxes, the structure of the Acheulian world. In: Milliken S, Cook J, editors. A Very Remote Period Indeed: Papers on the Palaeolithic Presented to Derek Roe. Oxford: Oxbow Books. p 19-27.

[46] Sharon G. 2008. The impact of raw material on Acheulian large flake production. Journal of Archaeological Science 35(5):1329-1344. 
[47] Drake NA, Blench RM, Armitage SJ, Bristow CS, White KH. 2011. Ancient watercourses and biogeography of the Sahara explain the peopling of the desert. Proceedings of the National Academy of Sciences 108(2):458-462.

[48] Drake NA, Breeze P, Parker A. 2013. Palaeoclimate in the Saharan and Arabian Deserts during the Middle Palaeolithic and the potential for hominin dispersals. Quaternary International 300:48-61. [49] Petraglia MD. 2011. Archaeology: trailblazers across Arabia. Nature 470(7332):50-51.

[50] Jennings RP, Singarayer J, Stone EJ, Krebs-Kanzow U, Khon V, Nisancioglu KH, Pfeiffer M, Zhang X, Parker A, Parton A. 2015. The greening of Arabia: Multiple opportunities for human occupation of the Arabian Peninsula during the Late Pleistocene inferred from an ensemble of climate model simulations. Quaternary International 382:181-199.

[51] Santonja M, Villa P. 2006. The Acheulian of Western Europe. In: Goren-Inbar N, Sharon G, editors. Axe age: Acheulian tool-making from quarry to discard. London: Equinox. p 429-478. [52] Roberts MB, Parfitt SA. 1999. Boxgrove: a Middle Pleistocene hominid site at Eartham Quarry, Boxgrove, West Sussex. London: English Heritage.

[53] Preece RC, Gowlett JAJ, Parfitt SA, Bridgland DR, Lewis SG. 2006. Humans in the Hoxnian: habitat, context and fire use at Beeches Pit, West Stow, Suffolk, UK. Journal of Quaternary Science 21(5):485-496.

[54] Gowlett JA. 2006. The early settlement of northern Europe: fire history in the context of climate change and the social brain. Comptes Rendus Palevol 5(1):299-310.

[55] White MJ, Plunkett S. 2004. Miss Layard Excavates: a Palaeolithic site at Foxhall Road, Ipswich, 1903-1905. Liverpool: Western Academic \& Specialist Press Limited.

[56] Hopkinson T, Nowell A, White M. 2013. Life histories, metapopulation ecology, and innovation in the Acheulian. PaleoAnthropology 2013:61-76.

[57] Stout D, Apel J, Commander J, Roberts M. 2014. Late Acheulean technology and cognition at Boxgrove, UK. Journal of Archaeological Science 41:576-590. 
[58] Kelley H. 1960. Bifaces de Dimensions Exceptionelles. Comptes-rendus du Congrès Préhistorique de France 16 session, Monaco, 1959:739-772.

[59] Pope M, Roberts M. 2005. Observations on the Relationship Between Palaeolithic Individuals and Artefact Scatters at the Middle Pleistocene Site of Boxgrove, UK. In: Gamble C, Porr M, editors. The Hominid Individual in Context: Archaeological investigations of Lower and Middle Palaeolithic landscapes, locales and artefacts. Abingdon: Routledge. p 81-97.

[60] Ashton N, McNabb J. 1994. Bifaces in perspective. In: Ashton N, David A, editors. Stories in Stone. London: Lithic Studies Society (Occasional Paper 4). p 182-191.

[61] Pitts M, Roberts M. 1997. Fairweather Eden. London: Century Books.

[62] Shennan S. 2002. Genes, Memes and Human History: Darwinian Archaeology and Cultural Evolution. London: Thames \& Hudson.

[63] Mithen SJ. 1994. Technology and Society during the Middle Pleistocene: Hominid Group Size, Social Learning and Industrial Variability. Cambridge Archaeological Journal 4(1):3-32.

[64] Gowlett J. 2005. Seeking the Palaeolithic individual in East Africa and Europe during the LowerMiddle Pleistocene. In: Gamble CS, Porr M, editors. The Hominid Individual in Context: Archaeological investigations of Lower and Middle Palaeolithic landscapes, locales and artefacts. London: Routledge. p 50-67.

[65] Bridgland DR, Lewis SG, Wymer J. 1995. Middle Pleistocene Stratigraphy and Archaeology Around Mildenhall and Icklingham, Suffolk: Report on the Geologists' Association Field Meeting, 27 June, 1992. Proceedings of the Geologists' Association 106:57-69.

[66] Hardaker T. 2012. The Artefacts from the Present Land Surface at the Palaeolithic Site of Warren Hill, Suffolk, England. Proceedings of the Geologists' Association 123:692-713.

[67] Cruse RJ, Bridgland DR, Callow P, Currant A, Hubbard RNLB, Debenham NC, Bowman SGE. 1987. Further Investigation of the Acheulean Site at Cuxton. Archaeologia Cantiana 104:39-81.

[68] Tester PJ. 1965. An Acheulean Site at Cuxton. Archaeologia Cantiana 80:30-60. 
[69] Wenban-Smith F. 2009. Medway Valley Palaeolithic Project. York: Archaeology Data Service (doi:10.5284/1000073).

[70] Shaw AD, White MJ. 2003. Another Look at the Cuxton Handaxe Assemblage. Proceedings of the Prehistoric Society 69:305-313.

[71] Hosfield RT, Green CP, editors. 2013. Quaternary History and Palaeolithic Archaeology in the Axe Valley at Broom, South West England. Oxford: Oxbow Books.

[72] Dennell RW, Martinón-Torres M, Bermúdez de Castro JM. 2011. Hominin variability, climatic instability and population demography in Middle Pleistocene Europe. Quaternary Science Reviews 30(11-12):1511-1524.

[73] Movius H. 1948. The Lower Palaeolithic Cultures of South-Eastern and Eastern Asia.

Transactions of the American Philosophical Society 38:329-420.

[74] Lycett SJ, Bae C. 2010. The Movius Line Controversy; The State of the Debate. World Archaeology 42:521-544.

[75] Wang W, Bae CJ, Huang S, Huang X, Tian F, Mo J, Huang Z, Huang C, Xie S, Li D. 2014. Middle Pleistocene bifaces from Fengshudao (Bose Basin, Guangxi, China). Journal of Human Evolution 69:110-122.

[76] Brumm A, Moore MW. 2012. Biface distributions and the Movius Line: A Southeast Asian perspective. Australian Archaeology 74:32-46.

[77] Dennell R. 2016. Life without the Movius line: the structure of the east and Southeast Asian Early Palaeolithic. Quaternary International 400:14-22.

[78] White MJ. 2000. The Clactonian Question: On the Interpretation of Core-and-Flake Assemblages in the British Lower Palaeolithic. Journal of World Prehistory 14(1):1-63.

[79] White MJ, Schreve DC. 2000. Island Britain - Peninsula Britain: Palaeogeography, Colonisation and the Lower Palaeolithic Settlement of the British Isles. Proceedings of the Prehistoric Society $66: 1-28$ 
[80] Ashton N, Lewis SG, Parfitt SA, Davis RJ, Stringer C. 2016. Handaxe and non-handaxe assemblages during Marine Isotope Stage 11 in northern Europe: recent investigations at Barnham, Suffolk, UK. Journal of Quaternary Science 31(8):837-843.

[81] Binford LR. 2001. Constructing Frames of Reference: An Analytical Method for Archaeological Theory Building Using Ethnographic and Environmental Data Sets. Berkeley, Los Angeles, London: University of California Press.

[82] Britton K, Grimes V, Dau J, Richards MP. 2009. Reconstructing faunal migrations using intratooth sampling and strontium and oxygen isotope analyses: a case study of modern caribou (Rangifer tarandus granti). Journal of Archaeological Science 36(5):1163-1172.

[83] Julien M-A, Bocherens H, Burke A, Drucker DG, Patou-Mathis M, Krotova O, Péan S. 2012. Were European steppe bison migratory? $18 \mathrm{O}, 13 \mathrm{C}$ and Sr intra-tooth isotopic variations applied to a palaeoethological reconstruction. Quaternary International 271:106-119.

[84] Lycett SJ, von Cramon-Taubadel N. 2008. Acheulean variability and hominin dispersals: a modelbound approach. Journal of Archaeological Science 35(3):553-562. 


\begin{tabular}{|c|c|c|c|c|c|}
\hline Region & $\begin{array}{r}\text { Groups } \\
\text { (n) }\end{array}$ & Value & $\begin{array}{r}\text { Number of } \\
\text { Moves per Year }\end{array}$ & $\begin{array}{r}\text { Total Distance } \\
\text { per Year (miles) }\end{array}$ & $\begin{array}{r}\text { Total Distance } \\
\text { per Year }(\mathrm{km})\end{array}$ \\
\hline \multirow[t]{2}{*}{ Tropical-subtropical Asia } & \multirow[t]{2}{*}{27} & Average & 12.3 & 124.6 & 199.4 \\
\hline & & Max. & 45.0 & 420.0 & 672.0 \\
\hline \multirow{2}{*}{$\begin{array}{l}\text { North Pacific coastal areas of } \\
\text { North America and Asia }\end{array}$} & \multirow[t]{2}{*}{28} & Average & 2.4 & 29.9 & 46.2 \\
\hline & & Max. & 8.0 & 90.0 & 144.0 \\
\hline \multirow{2}{*}{$\begin{array}{l}\text { Subarctic and continental mid- } \\
\text { latitude forests of North } \\
\text { America and Asia }\end{array}$} & \multirow[t]{2}{*}{37} & Average & 11.2 & 265.8 & 425.3 \\
\hline & & Max. & 20.0 & 496.0 & 793.6 \\
\hline \multirow[t]{2}{*}{ Arctic } & \multirow[t]{2}{*}{21} & Average & 7.3 & 228.3 & 347.9 \\
\hline & & Max. & 16.0 & 501.0 & 801.6 \\
\hline
\end{tabular}

Table 1. Mobility for various hunter-gatherer groups (data from Table $8.04^{81}$ ). 


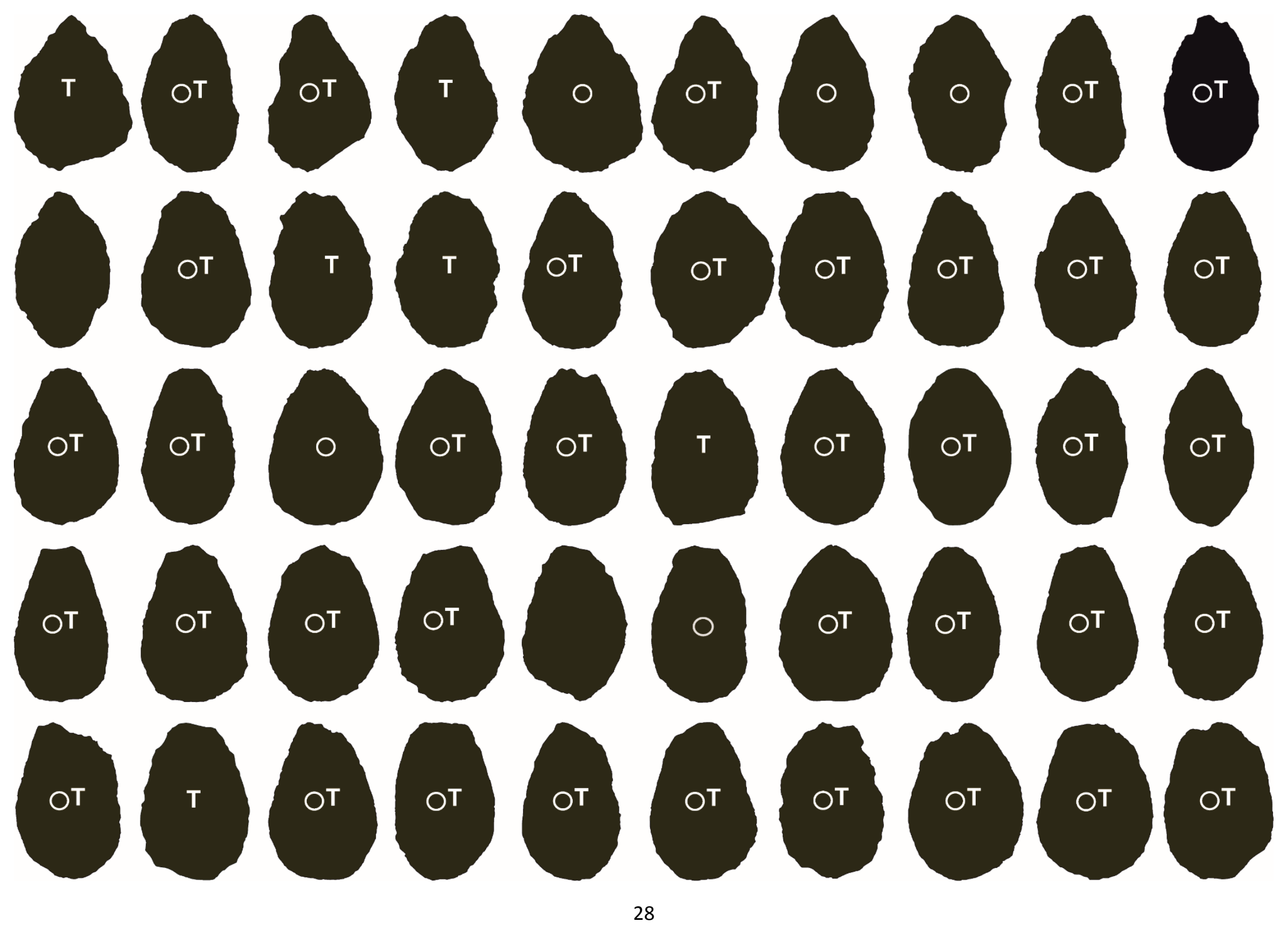


Figure 1. Silhouette of 50 Boxgrove handaxes, ${ }^{20}$ selected by random number generator. Positioned from left to right and top to bottom on the basis of tip width at Roe's $B_{1}$ (width of tip at $20 \%$ of length from tip to base). Narrowest at top left and widest at bottom right. O: handaxe with cutting edge all around the circumference, or nearly so. T: tranchet. Handaxes not to scale. 


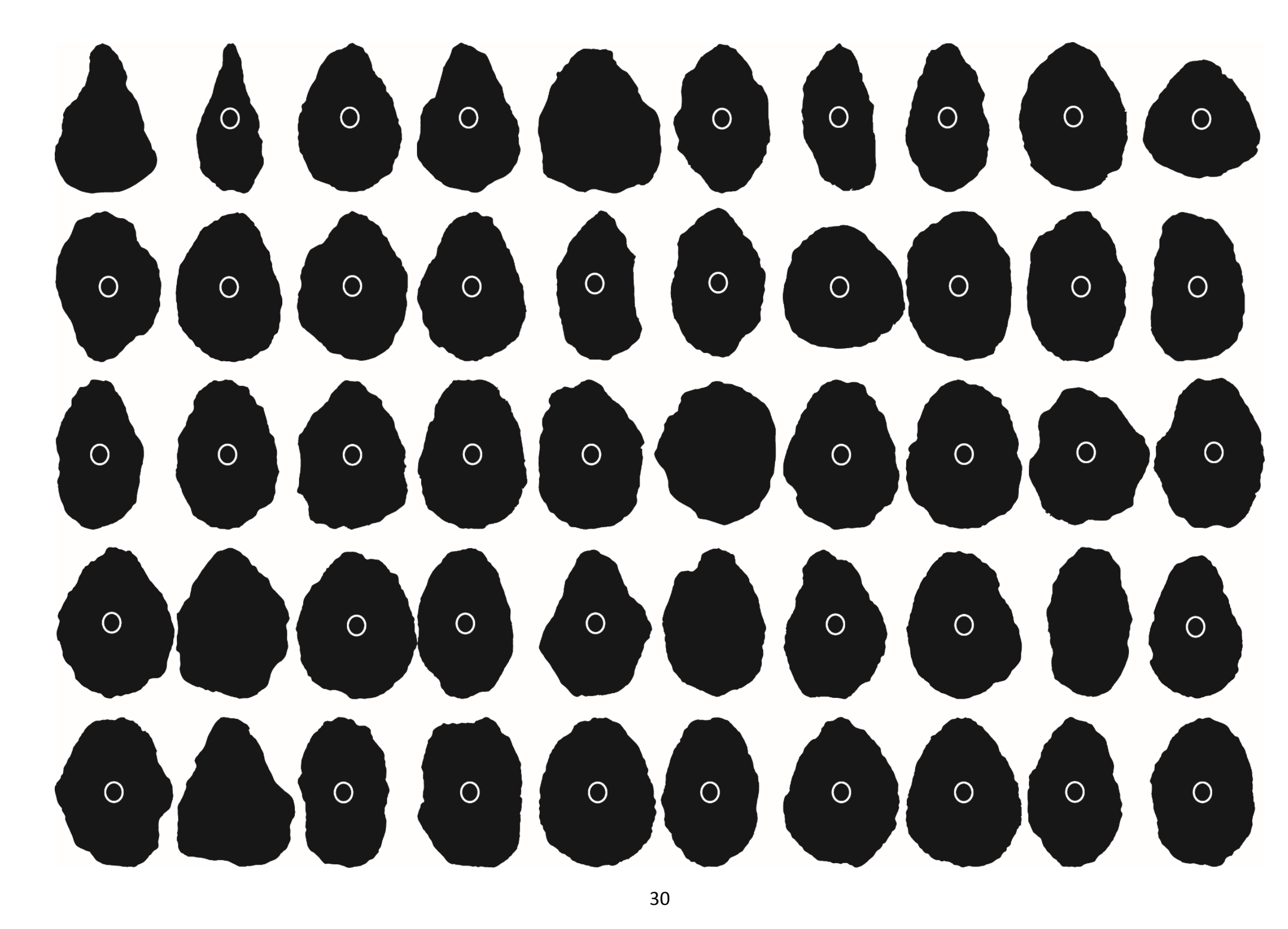


Figure 2. Silhouette of 50 Warren Hill handaxes, ${ }^{20}$ selected by random number generator. Positioned from left to right and top to bottom on the basis of tip width at Roe's $B_{1}$ (width of tip at $20 \%$ of length from tip to base). Narrowest at top left and at widest bottom right. O: handaxe with cutting edge all around the circumference, or nearly so. Handaxes not to scale. 


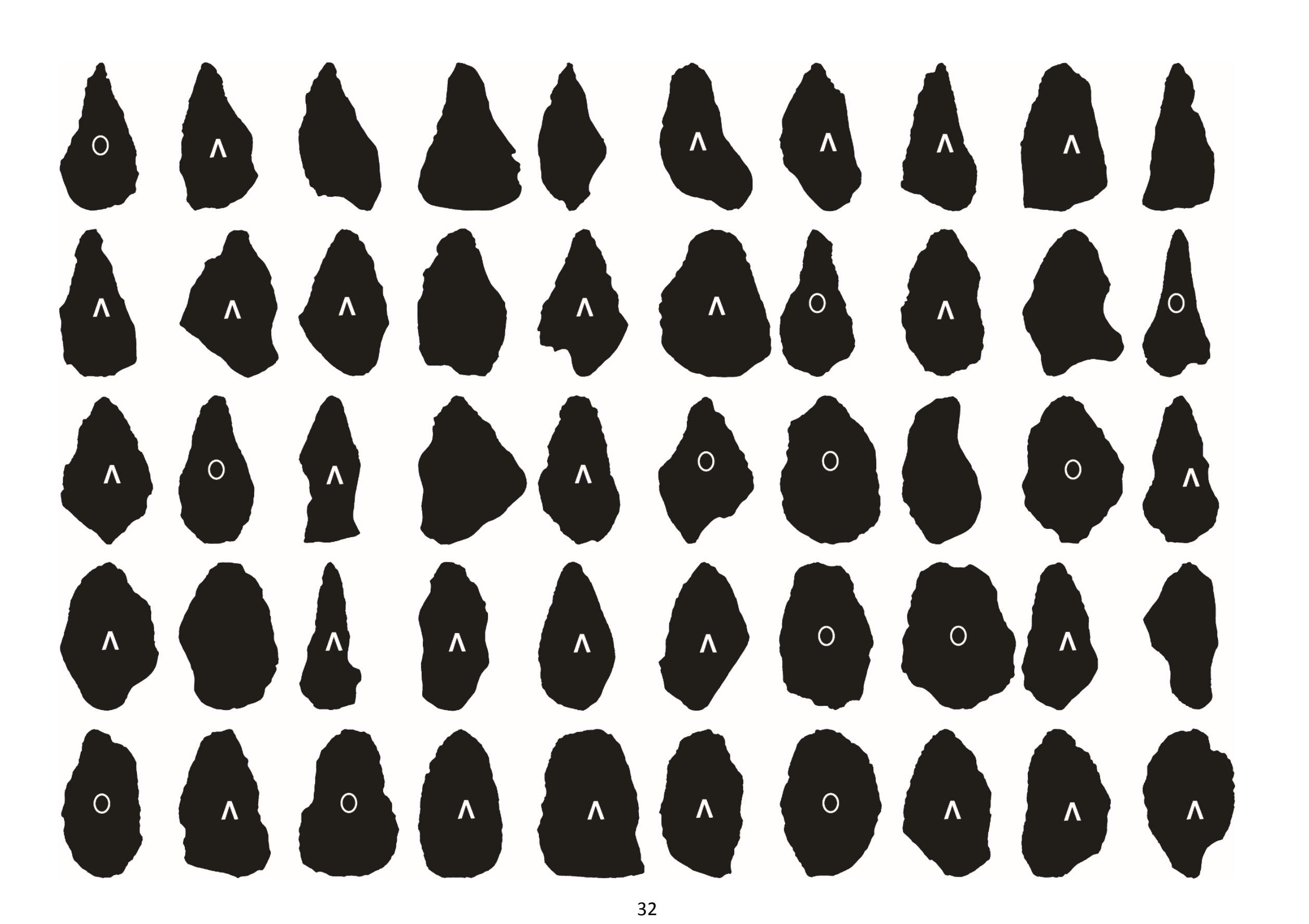


Figure 3. Silhouette of 50 Cuxton handaxes, ${ }^{20}$ selected by random number generator. Positioned from left to right and top to bottom on the basis of tip width at Roe's $B^{1}$ (width of tip at $20 \%$ of length from tip to base). Narrowest at top left and widest at bottom right. O: handaxe with cutting edge all around the circumference, or nearly so. ${ }^{\wedge}$ : handaxe with cutting edge confined to tip (upper third) and middle (middle third). Handaxes not to scale. 

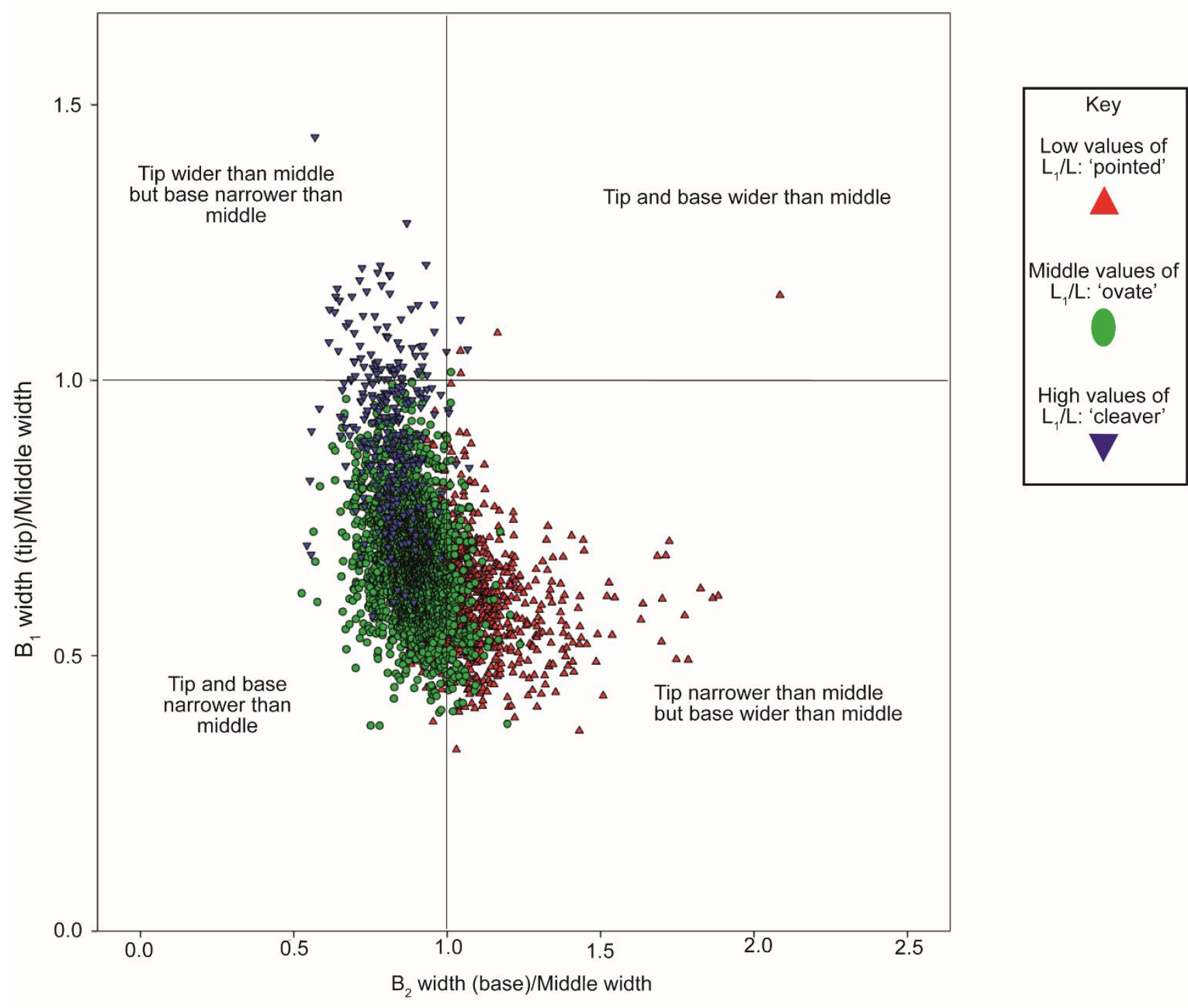
Figure 4. Handaxes from the Marshall et al. data-set. ${ }^{20}$ The data cloud comprises 3,453 handaxes, cleavers and other large cutting tools, all unbroken, in twenty two different raw materials from twenty one different sites in the UK, Near East, South and Eastern Africa. $\mathrm{B}_{1}$ is the width of the handaxe tip measured at $20 \%$ of length from tip to base. $B_{2}$ is the width of the handaxe base measured at $20 \%$ of length from base to tip. Middle is the width of the handaxe at $50 \%$ of length. Roe's 'pointed', 'ovate' and 'cleaver' measurements are based on the ratio of $L_{1} / L$ (position of the point of maximum width measured from the base/length of handaxe). 


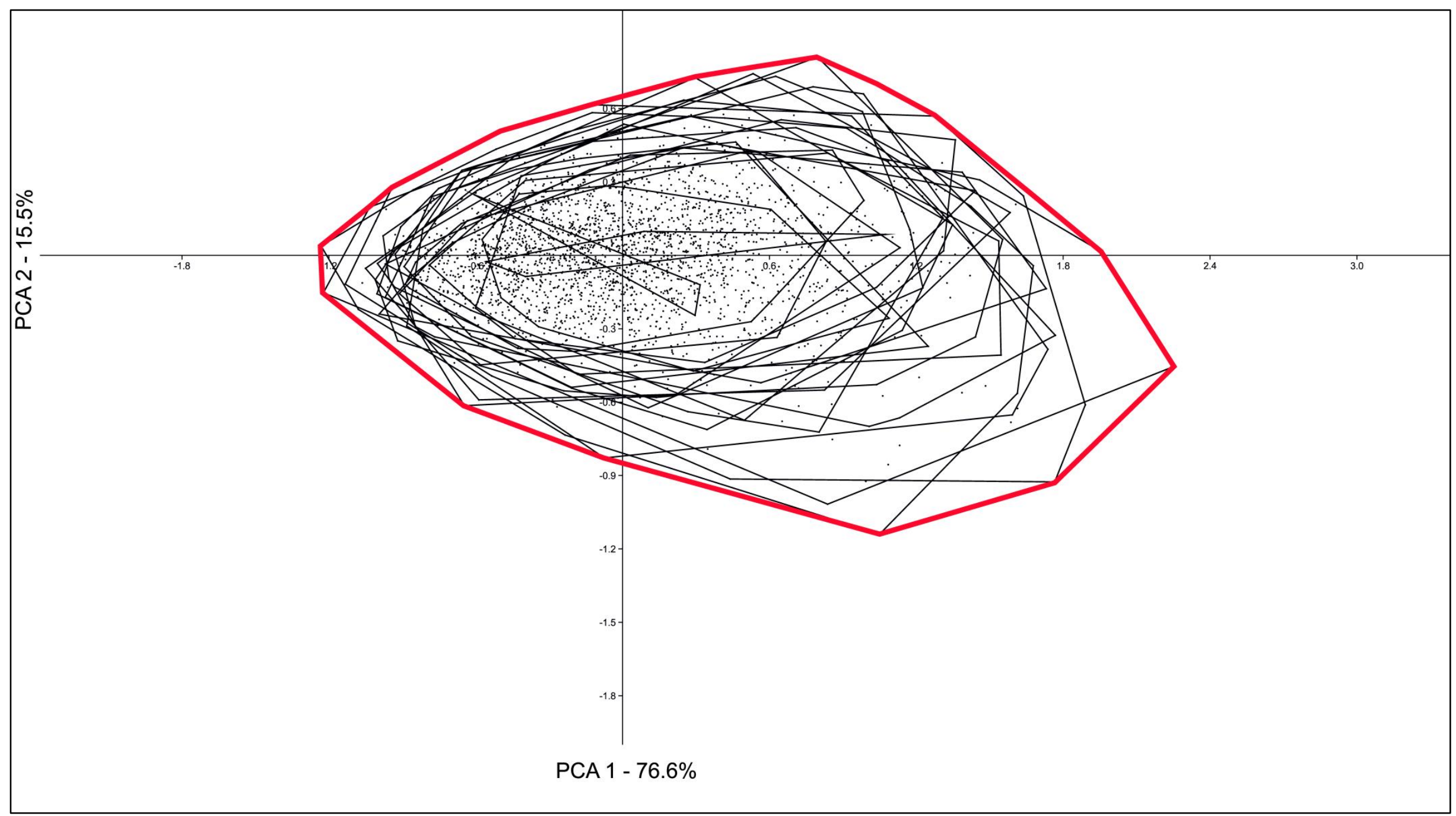

Figure 5: Principle Components Analysis of 2,601 handaxes from the Marshall et al. data-set, ${ }^{20}$ using 5 proxy measures for shape (B [maximum width], $B_{1}$ [width at $20 \%$ of length from tip to base], $B_{2}$ [width at $20 \%$ of length from base to tip], $B_{3}$ [width at mid-point from base to tip], $L_{1}$ [position of the point of 
maximum width measured from the base]). Size was removed from all 5 variables following the GM method. ${ }^{84}$ Handaxes from 21 different sites. Black lines represent convex hulls = the outer limits of the dot (artefact) distribution for each site. Red line = outer distribution for the whole data set. 


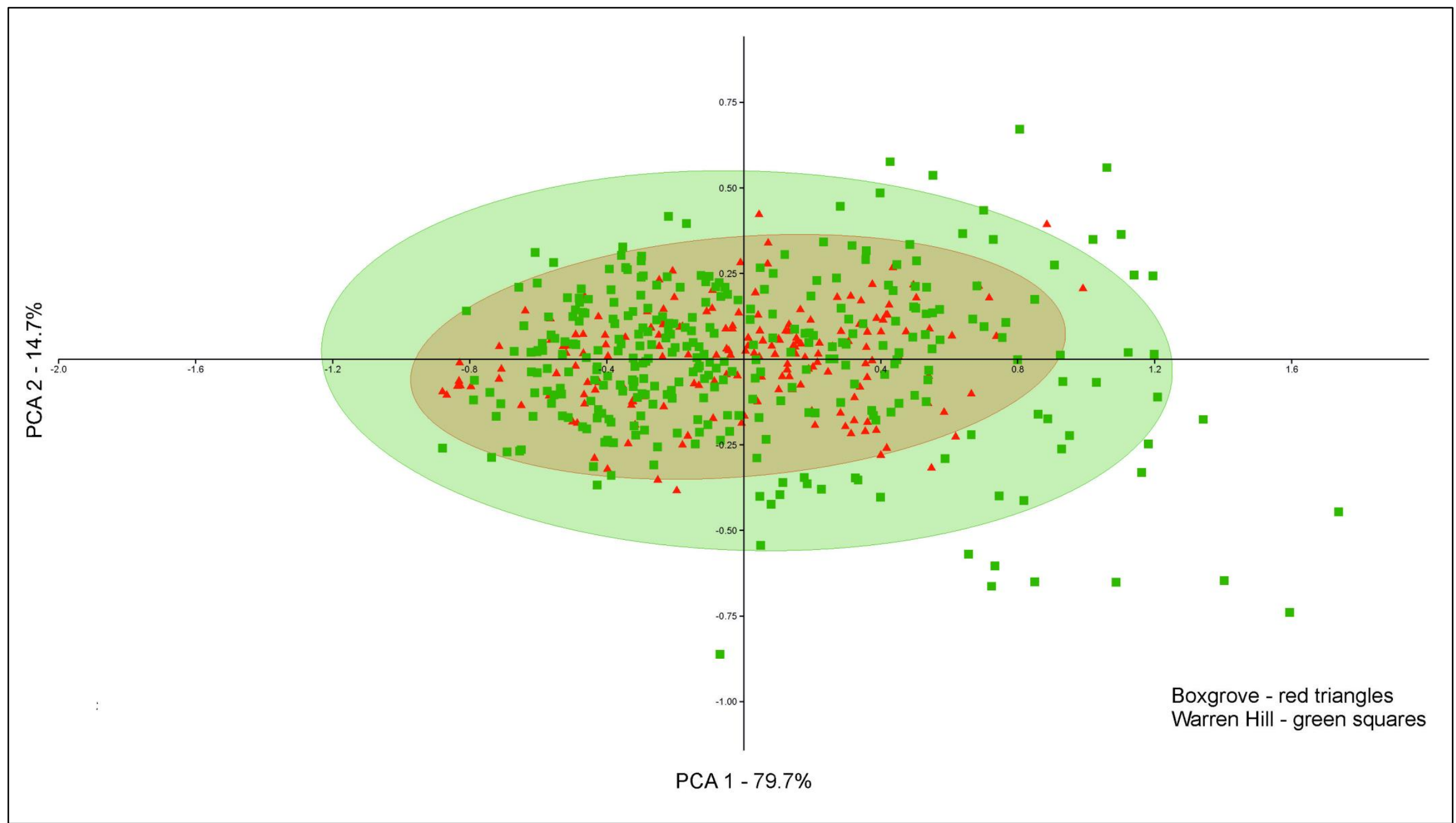


Figure 6: Principle Components Analysis of 498 handaxes from Boxgrove and Warren Hill (from the Marshall et al. data-set ${ }^{20}$ ) using 5 proxy measures for shape ( $B$ [maximum width], $B_{1}$ [width at $20 \%$ of length from tip to base], $B_{2}$ [width at $20 \%$ of length from base to tip], $B_{3}$ [width at mid-point from base to tip], $L_{1}$ [position of the point of maximum width measured from the base]). Size was removed from all 5 variables following the GM method. ${ }^{84}$ 